\title{
Türkçeden Gürcüceye yapılan şiir çevirilerinde nitelik sorunu (Nazım Hikmet şiirleri)
}

\section{Gül Mükerrem ÖZTÜRK1}

\begin{abstract}
APA: Öztürk, G. M. (2019). Türkçeden Gürcüceye yapılan şiir çevirilerinde nitelik sorunu (Nazım Hikmet şiirleri). RumeliDE Dil ve Edebiyat Araştırmaları Dergisi, (Ö5), 441-456. DOI: 10.2900o/rumelide.606274.
\end{abstract}

\section{$\ddot{O} \mathbf{z}$}

Gürcüler ve Türkler arasındaki ilişkiler uzun bir geçmişe dayanmaktadır. İki millet arasındaki bağın oluşmasındaki en önemli etkenlerden biri de çeviridir. Şiir de yapılan çeviriler içinde önemli bir yere sahiptir. Özellikle 1960'lı yıllardan itibaren Türkçeden Gürcüceye yapılan yazın ve şiir çevirilerinde artış görülmektedir. Bu çalışmamızda, Nazım Hikmet’in 1952 yılında Tiflis’te Vakhtang Kekelidze tarafından Gürcüceye çevrilen şiirlerini ele alacağız. Şiirleri çeşitli açıdan incelenerek, inceleme sonunda kabul edilebilirlik - yeterlilik bağlamından yola çıkarak Türkçeden Gürcüceye yapılan çeviri şiirlerinin nitelik boyutuna dair çıkarımlar yapılacak olup çă̆daş Türk şiirinde önemli yeri olan Nazım Hikmet'in şiirlerinden örnekler alınarak karşılaştırmalı olarak irdelenecektir. Çeviri bilimcilerin şiir çevirisine dair görüşlerinin ve bu edime farklı yaklaşımların betimlendiği ilk bölümü takiben, Türkçeden Gürcüceye çevrilen şiirleri anlatılacaktır. Amaç, şiir çevirisindeki zorlukları anlatan bir çalışma ortaya koymanın yanı sıra, şair-çevirmenin çevirileri ışı̆̆ında şiir çevirisinde olasılıkları irdelemek ve bu olasılıkları çeviribilimin bakış açısından değerlendirmektir. Çalışma üç kısımdan oluşmaktadır: İlk kısımda, çeviri eylemini yeniden yazma eylemi olarak ele alan yaklaşımlar incelenmiş, ikinci kısımda, erek metinleri inceleme çerçevesini oluşturan kavramlar ele alınmıştır. Üçüncü kısımda ise erek metinlerdeki metaforların nasıl yeniden yaratıldığı metinlerden alınan örneklerle tartışmaya açılmaktadır. Bu çalışma sonucunda, Nazım Hikmet şiirlerinin çevirilerinde, somutlaştırma, deyiş kaydırma, yerlileştirme, yabancılaştırma gibi çeviri stratejilerinin kullanıldığı görülmüş ve çevirmenin erek metindeki metaforların yaratım sürecinde metaforik bir yeniden yazma eylemi gerçekleştirdikleri sonucuna ulaşılmıştır.

Anahtar kelimeler: Çeviri, Nazım Hikmet, Vakhtang Kekelidze, karşılaştırmalı, çeviribilim.

\section{The problem of quality in poetry translations from Turkish to Georgian (poems by Nazim Hikmet)}

\begin{abstract}
The relations between Georgians and Turks are based on a long history. Translation is one of the most important factors in the formation of the link between the two nations. Poetry has an important place in the translations. Especially in the 1960s, there has been an increase in the literature and poetry translations from Turkish to Georgian. In this study, we will examine Nazım Hikmet's poems translated into Georgian language by Vakhtang Kekelidze in Tbilisi in 1952. The poems will be examined from a variety of perspectives and from the context of acceptability - proficiency, the inference will be made on the qualitative dimension of the translation poems from Turkish to Georgian. Following the first part of translation scientists' views on poetry translation and different
\end{abstract}

1 Dr. Öğr. Üyesi, Recep Tayyip Erdoğan Üniversitesi, Fen Edebiyat Fakültesi, Gürcü Dili ve Edebiyatı Bölümü (Rize, Türkiye), gul.ozturk@erdogan.edu.tr, ORCID ID: 000o-0003-4730-6720 [Makale kayıt tarihi: 06.05.2019-kabul tarihi: 19.08.2019; DOI: 10.29000/rumelide.606274] 


\begin{abstract}
approaches to this act, poems translated from Turkish into Georgian will be explained. The aim is to explore the possibilities of poetry translation in the light of the translations of the poet-translator, and to evaluate these possibilities from the point of view of translation studies. The study consists of three parts: In the first part, the approaches that take the translation action as an act of rewriting are examined. In the second part, the concepts that constitute the framework of the examination of the texts are examined. In the third part, how the metaphors in the texts are recreated is discussed with the examples taken from the texts. As a result of this study, it was seen that translation strategies such as concretization, translation, indenisation and alienation were used in the translations of Nazım Hikmet's poems.
\end{abstract}

Keywords: Translation, Nazim Hikmet, Vakhtang Kekelidze, comparative, translation studies.

\title{
Giriş
}

"Şiir gerek içerik, öz, gerekse söze dönüştürme açısından özgün, etkilemeye, duygulandırmaya yönelik, yaratıcı niteliği taşıyan bir söz sanatıdır”(Aksan 2013:14). Ayrıca gerek Batı'da gerekse Doğu'da şiire dair yüzlerce tanım bulunmaktadır. Bu noktada Haedens'in "Şiir tarif edilebilseydi yüz türlü değil, bir türlü tarif olurdu" şeklindeki şiir hakkındaki düşüncesinden de bahsetmek yerinde olacaktır (Haedens 1961: 245). Ayrıca F. Jones'e göre şiir, yüksek sosyal değeri olan kültürel bir ürün iken (Jones 2010: 227), Y. Bonnefoy'a göre şiir, bir araç, bir düşünsel ve tinsel önermedir; dolayısıyla bir sonuç veya ürün değildir (Bonnefoy 1992: 187-188). Bütün bu tanımlamalardan yola çıkarak şiirin bir dilden başka bir dile çevrileceğinin ne kadar zor bir iş ve emek gerektireceğinin bir göstergesidir diyebiliriz. Şiir çevirisi zor bir iştir. Geçmişten günümüze dek Almanca, İngilizce ve Fransızca dillerinden Türkçeye birçok şiir çevirisi yapılmaktadır. Bu dillere ek olarak Gürcü dilinden de söz edebiliriz. Sovyet döneminde Türk Gürcü şairlerin sadece birkaç şiiri çevrilmiştir. Bu da Türk-Gürcü edebi ilişkilerin o dönemde önemli bir yere sahip olduğunun yadsınamaz bir gerçekliğini ortaya koymaktadır. Bu çalışmada, Gürcü Türkolog, çevirmen Vakhtang Kekelidze tarafından 1952 yılında Türk edebiyatının önemli şairlerinden olan Nazım Hikmet’in "Nazım Hikmet ve Seçilmiş Şiirleri” adlı başlıkla Gürcüceye çevirerek Gürcü okurlarla buluşturmuştur. Amaç, Türk kültürü ile diğer kültürler arasında bağdaştırıcı bir rol oynayan bu şiirlerinin kaynak metin ve erek metini karşılaştırmalı ele almaktır. Şiir çevirisinin zor olduğunu ortaya koyan bir çalışma oluşturmaktır.

\section{Yabancı bilim adamlarının şiir çevirisine dair görüşleri}

Her ne kadar şiir çevirileri en az 2000 yıldır kabul gören bir uygulama olarak yapıla gelse de, günümüze kadar gelen kuramsal tartışmalar çoğunlukla şiirin çevrilmesinin mümkün olup olmadığ hususuna odaklanmıştır (Connolly 2005:170-176).

Şiiri çevirmek, hangi kültürler, diller veya tarihî anlar söz konusu olursa olsun, alıcı kültürde bir şiir yaratmakla özdeşleştirilebilir. Kaynak metine bir eş değerlik sağlama çabası güden bir şiirsel etkinin yaratımı ile aslında, değişik bir dilde ve kültürde başka bir şiir yaratılmış olur. Böylelikle çevirinin öznesi olan kaynak şiir, çeviri sürecinde yok olur ve yerini bir anlamlama ağına bırakır. Bu ağ ise, metinler arası, söylemdeş, göstergeler arası bir metin olarak, alıcı kültürde yerini alır (Venuti 2011: 128).

Eğer şiir çevirisi, yalnızca kaynak şiirin çözümlenmesini, erek dilde yeniden kurgulanmasını ve yapılandırılmasını içerseydi diller arası bir işlemden belli eş değerliliklerin sağlandığı ve biçemsel ödünlemeden öteye geçmeyen bir uğraş olarak nitelendirilirdi (Esteban 2001:331). Ancak şiir çevirisi 
söz konusu olduğunda betimsel düzyazıda sorulmayan birçok soru gündeme gelmektedir ve bu bağlamda, düz anlamdan öte yan anlamlar ön plana çıkmaktadır (Dahlgren 2000: 97).

Şiir çevirisinde genelde sözcüklerin veya söz dizimsel yapıların kendileri değil, çıkarılan anlamların aktarımı ön planda olacaktır. Zaten, diller arasındaki farklılıklardan ve şiirin biçimsel ve biçemsel özelliklerinden dolayı şiirlerin, gerçek anlamda, sadık çevirilerini yapmanın mümkün olmadığı söylenebilir (Shupala 2000:14).

Ünlü çeviribilimci Andre Lefevere'e göre şiir çevirmeni; çevirisini yapacağı şiiri öncelikle iyi bir şekilde kavramalı, metnin sosyo-kültürel arka planına hâkim olmalı, iyi bir dilbilgisi düzeyine sahip olmalı ve şiirde var olan biçemi hedef dildeki şiire yansıtabilmelidir. Son olarak şiirde yer alan geleneksel, kültürel ifadeleri çeviri de etkin bir biçimde dile getirmelidir (Lefevere, 1975:49). Ayrıca Lefevere' e göre şiir çevirisi ile ilgili bazı stratejilere vurgu yapmaktadır. Öncelikle; kaynak dildeki seslerin hedef dilde tekrar oluşturulması gerektiğini ifade etmekte ve böylelikle sessel çevirinin amacına uygun hareket edileceğine dikkat çekmektedir. Aynı şekilde kaynak dildeki kelimelerin hedef dildeki tam karşılıkları da kelimesi kelimesine çeviri kapsamında yerine getirilmelidir.

Toury ise çeviri sürecini baştan sona kadar ele alan bazı standartların olduğunu ifade etmektedir (Toury 1980: 51-52). Bunlar: çeviri öncesi norm, çeviri sürecindeki norm ve öncül normlardan oluşmaktadır. Süreç öncesi normlar incelendiğinde, çevrilecek metnin seçimi, çevrilecek metnin alınacağı kaynaklar, çevrilecek metnin türü, çevirinin doğrudan kaynak metinden mi yoksa ara dilden yapılacağına ilişkin normlar olduğu anlaşılmaktadır. Çeviri süreci normları, çevirmenin çeviri eylemi sırasında aldığı kararları yöneten normlardan oluşmaktadır. Çeviri de kullanım biçimi önemlidir. Öncül normlara bakıldığında ise, çevirmenin çeviriye ilişkin takındığı tavır ön plana çımaktadır. Bu ilk tavırdan hareketle, çevirmen için iki seçenek yer almaktadır. Çevirmen kaynak metne ve içerdiği normlara öncelik tanıyabilir. Şayet bu durumu benimsemezse, hedef dizgede etkin olan normları üstün tutmuş da olabilir. Öncü normlar çevirmenin vermiş olduğu bu kararlar ile alakalıdır.

Edmond Cary, çeviri işlemi farklı dillerde ifadesini bulan metinlerarasındaki eşdeğerliklerin sağlanılması işlemi olarak tanımlar ve bu eşdeğerliklerinin her iki metnin doğasına, kullanım amaçlarına, iki halkın kültürü arasındaki ilişkilere, onların ahlakı, duygusal ve entelektüel birikimlerine bağlı olduğunu vurgular (Cary 1996:97).

Gürcü bilim adamı Dali Pancikidze ise çeviriyi; dilsel iletişime ait bir tür olduğunu, herkesin kendi boyutuyla daha bağımsız bir şekilde makro dilbilimine yerleştiği ve metnin dil bilgisel, ulaşım, sosyal, pragmatik dil bilgisel, psikolinguistik gibi bütün disiplinlerle sıkı bağlantılı olduğunu diğer yandan, çevirinin teorik olarak öğrenilmesinde dil bilimsel inceleme metotlarının kullanımının iletişimsel yönünü ortaya çıkarmış ve bu da onun işlevini betimlemesiyle iletişime özgü türün çevirinin temelinde oluştuğunu göstermektedir (Pancikidze 1993: 2-3).

Fransız bilim adamı Rosenzweig, çeviriye değişik yönden yaklaşarak ele almaktadır: O çeviriyi "iki efendiye hizmet etmek" olarak değerlendirmektedir. Ona göre, biri kendi içindeki yabancıdır bu efendilerin, diğeri ise yapıtı kendisine mal etme arzusu içinde olan okurdur. Bu durum bir çelişkidir. Bu çelişki aslında hem sadakat arzusu hem de ihanet kuşkusunu içinde barındıran bir sorunsaldan kaynaklanmaktadır (Ricoeur 2008: 10). 


\section{Türk bilim adamlarının şiir çevirisine dair görüşleri}

Şiir çevirisi zor bir uğraştır. Şiirde anlam her şey demek değildir, salt anlamın çevrilmesi şiirin çevrildiğini göstermez. Yalnızca anlamı çevirmek şiirin konusunu ortaya koymaktır. Asıl zor olan ise şairin üslubundan kaynaklanmaktadır, her şiirin anlatım biçimi ayrıdır, kendisine ve şairine özgüdür işte şiir çevirisinde aktarılamayan yapı da budur. Bir başka ifadeyle öz ve biçim buradan kaynaklanmaktadır. Bir şairin yaratıcılı̆̆ını gösteren bunlardır. Şiir de yaratıcı olan şaire ait olduğundan aktarılmasında zorluk çımmaktadır (Aksoy 2002:131-132).

Bir şiiri tümüyle, yan anlamlarıyla hiçbir şey yitirmeden başka bir dile aktarmak olanaklı değildir. Şiir çevirmek salt olarak kaynak dille hedef dil arasında bir karşılık bulma etkinliği olmadığından; bazı kelimelerin sesbilimsel niteliğinden, anlam kaymalarına kadar çok farklı güçlüklere sahip olduğundan, kaynak dildeki tüm anlamı ve şiirin biçemini, sessel unsurlarının hepsini kapsayan bir şiir çevirisi elbette mümkün değildir (Gürsel 1978:155).

Eyüboğlu, şiire asıl güzelliğini veren şeyin sesler, çağrışımlar, ritimler olduğunu, bütün bunları hedef dilde yeniden yaratmanın mümkün olmadığını söyleyerek şiirin çevrilemeyeceği hissini verdikten sonra şöyle devam eder: ... insanoğlu, şiiri öteden beri dilden dile çevire gelmiş, nice şairleri yalnız çevirilerden tanımış, sevmiş, Homeros, Hayyam, Hafız, Shakespare gibi şairlerin kaba yanlışlarla çevirileri bile nice insanları büyülemiş. Demek ki şiirin kendinde olduğu gibi çevirisinde bile aklımızı, gündelik mantığımızı aşan bir taraf var. Demek şiirde seslerin, kelimelerin ötesinde öyle bir anlam var ki kolu kanadı kırılsa da insandan insana, dilden dile geçebiliyor (Eyüpoğlu 1983:10).

Durusoy, şiir çevirisinin çok zor ama bir o kadar da zevkli olduğunu belirttikten sonra, kimi yazar ve sanatçının şiir çevrilemez diye bir kuram üretmek istediklerini oysaki bunun doğru olmadığını Margurite Yourcenar'ın, Konstantin Kavafis şiirlerini düzyazı olarak Yunancadan Fransızcaya mükemmel bir şekilde çevirdiği gibi, şiirin kim ne derse çevrileceğini, şiirde kör bir sadakat olamayacağını, çevirmen yaratıcılığının da şiir çevirisinde çok önemli olduğunu ifade etmektedir (Durusoy 1998:24).

\section{Türkçeden Gürcüceye çevrilen şairlerin eserleri}

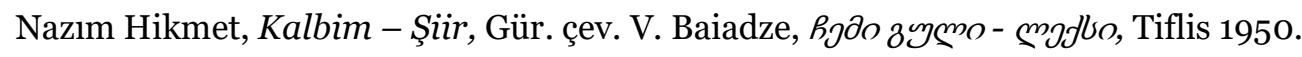

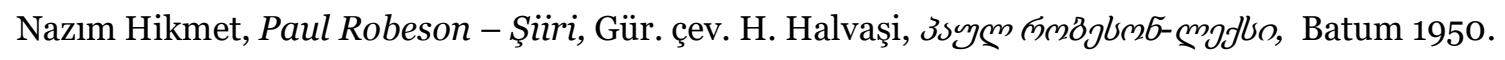

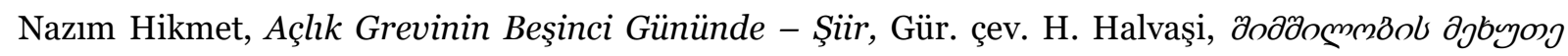
sosgzo - çgllo, Batum 1950.

Nazım Hikmet, Zoya - Destan. Gür çev. K. Lortkipanidze, A. Mirtskhulava, \&̀mos, Tiflis 1951.

Nazım Hikmet, Mor Menekşe, Aç Dostlar Ve Altın Gözlü Çocuk - Şïir, Gür. çev. V. Laperaşvili, olıbogjøo

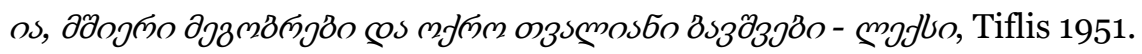

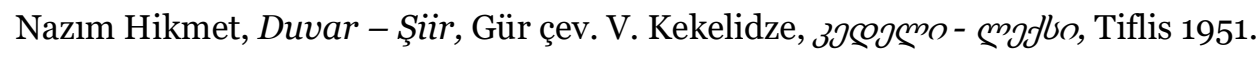

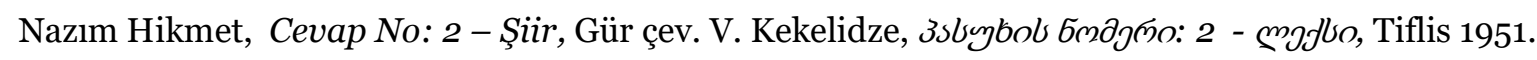

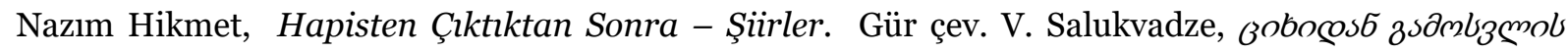

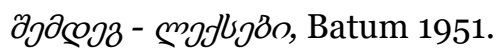

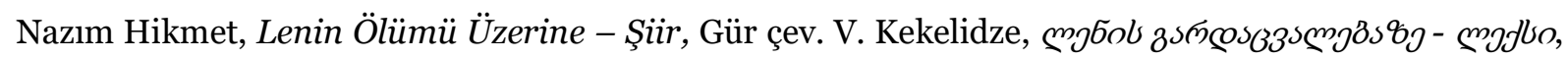
Tiflis 1951. 
Nazım Hikmet, Gömlek, Pantolon, Kasket ve Fötre Dair - Şïr, Gür çev. V. Kekelidze, зj历sбzo,

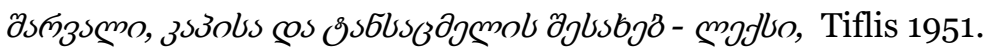

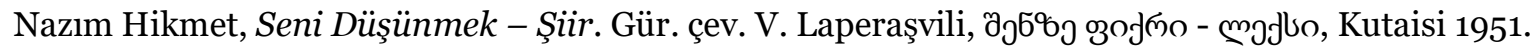

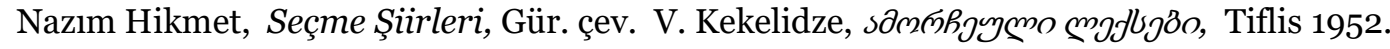

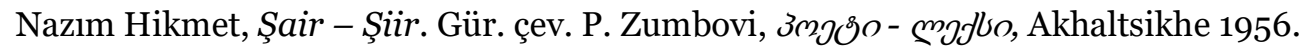

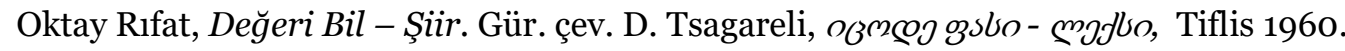

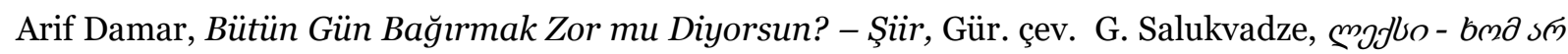

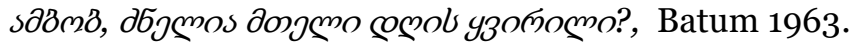

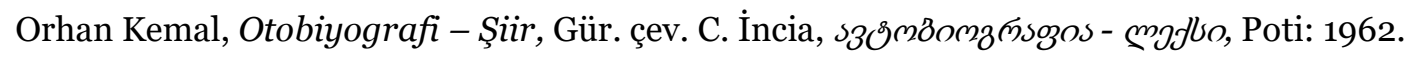

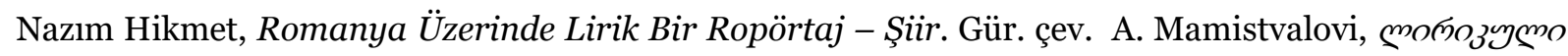

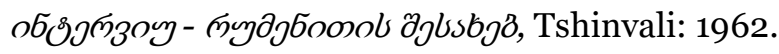

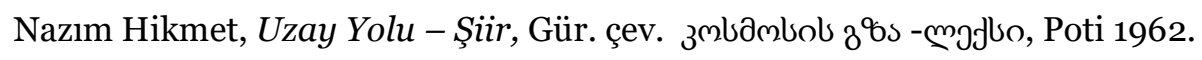

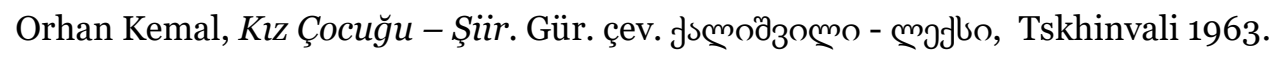

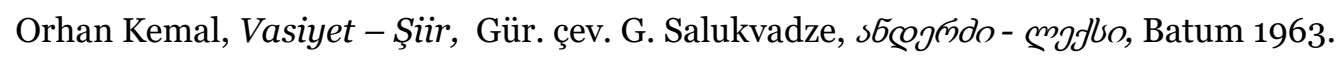

Muazzez Menemencioğlu, Bizim Evimiz - Şïr. Gür. çev. G. Salukvadze, ค3jбo bsbeso- mołluo, Batum 1963.

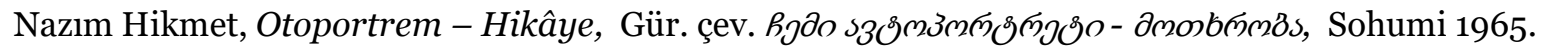

Nazım Hikmet, Şiirleri, Batum 1965. Açara ASSR Sakhelgami: "Paligrapi” Yay.

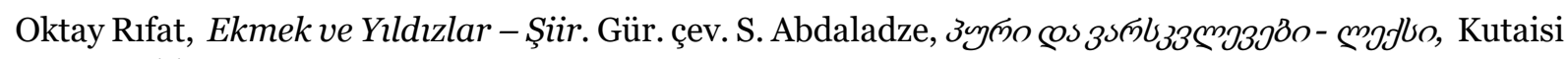
1966.

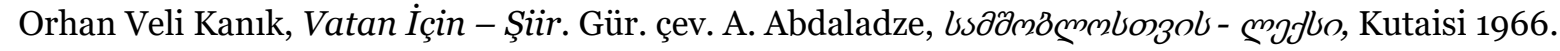

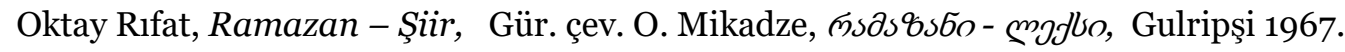

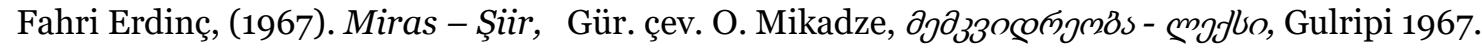

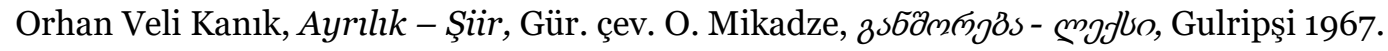

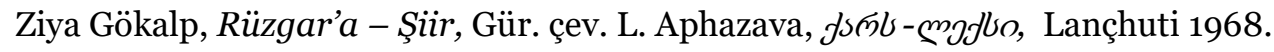

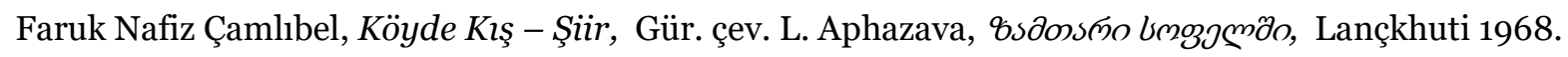

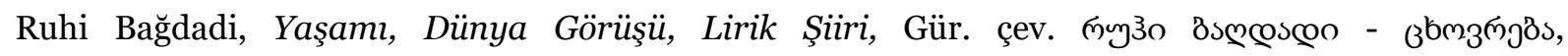

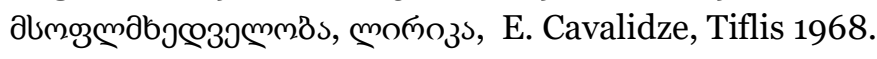

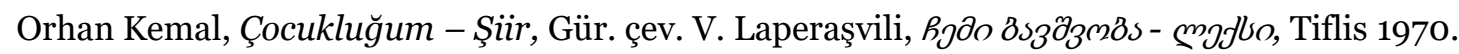

Şakulaşvili, G. (1970). Seyahatnamenin Azerice Şiirleri Teymuraz’ın Defterine Göre. Tiflis.

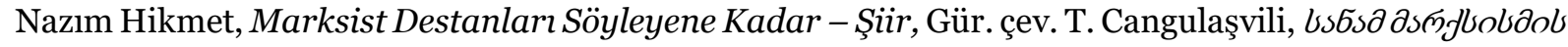
cojboss6joo - çjlbo, Tiflis 1970.

Nazım Hikmet, Annemin Adıyla, Annem - Şïr, Gür. çev. V. Laperaşvili, @эœsßjaob usbjmon,

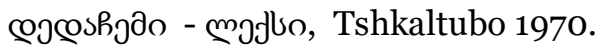

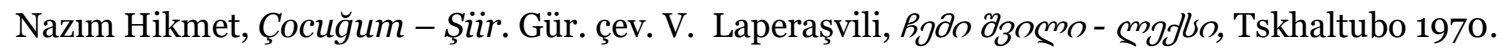

Nazım Hikmet, Piyesler, Gür. çev. G. Batiaşvili, Зogıgßo, Tiflis 1970.

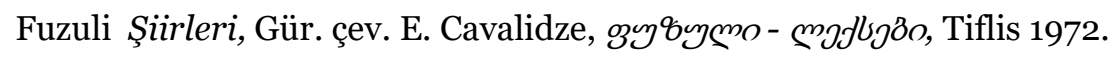




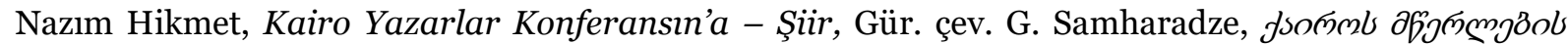

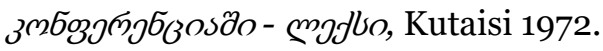

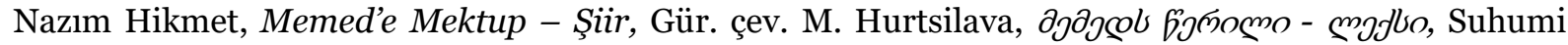
1972.

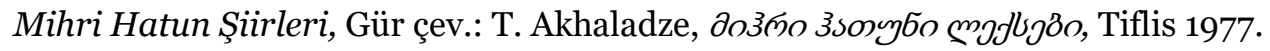

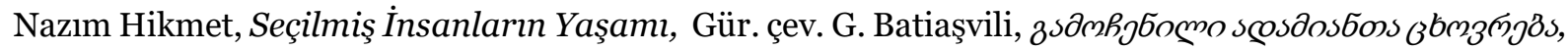
Tiflis 1977.

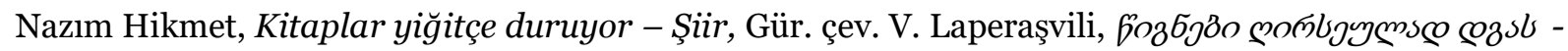
modbo, Tiflis.

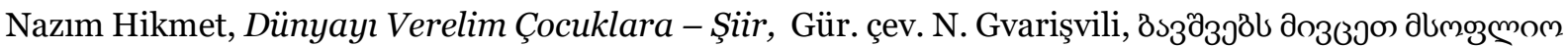
- mojbo. Tiflis 1983.

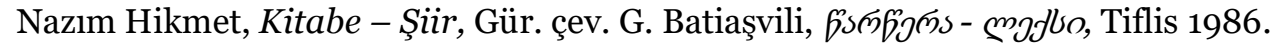

Fazıl Hüsnü Dağlarca, Şiïleri - Seyahat, Teklif, Dualite, Ordu’yu Açmak, Gür. çev. çəłlıgoo -

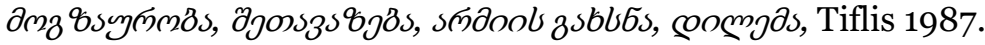

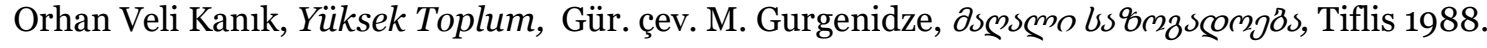

Türk Şiiri (Kısa Ders) Kitabı, Hazırlayan: Elizbar Cavelidze, Tiflis 1988.

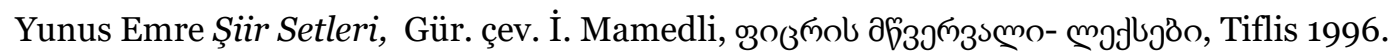

Emre Yunus, Şïrleri, Gür. çev. İ. Mamedli, ભmgłlıgo, Tiflis 1886.

Türk Sembolizm Tarihi (Ahmet Haşimin Şïirini Anlamak), Hazırlayan: E. Cavalidze, Tiflis, "Ena da Literatura" Yay. 2006.

Türk şiiri antolojisi Hazırlayanlar ve Çevirenler: Kharebava, M., ve Elerdaşvili, A., Tiflis: "Saçino" Yay., 2018.

\section{Seçili şiir çevirilerinin karşılaștırmalı incelenmesi}

Gürcü Türkolog, çevirmen Vakhtang Kekelidze tarafından 1952 yılında Türkçeye çevrilen 34 adet şiirden 4 şiir metni, gerek içerik gerekse biçim yönünde yeterlilik ve kabul edilebilirlik bağlamında ele alınıp, eş değerlik temelinde karşılaştırmalı olarak incelenmiştir. Kaynak metni hedef dile aktarırken çevirmenin dilsel anlamda karşılaştı̆̆ sorunlara, yaptı̆̆ çekilmiştir. Kelime seçimlerinden, biçimsel ve kültürel farklılıklardan dolayı oluşan sorunlar ve bu sorunların çözümü için çevirmenin metodu ele alınmaya çalışılmıştır.

\section{Kaynak Metin 1}

KALBİM

Göğsümde 15 yara var!.

Saplandı göğsüme 15 kara saplı bıçak!.

Kalbim yine çarpıyor,

Kalbim yine çarpacak! !!

Göğsümde 15 yara var!

Sarıld 15 yarama 
Kara kaygan yılanlar gibi karanlık sular!

Karadeniz boğmak istiyor beni,

Boğmak istiyor beni!

Kanlı karanlık sular! !!

Saplandı göğsüme 15 kara saplı bıçak.

Kalbim yine çarpıyor,

Kalbim yine çarpacak! ..

Göğsümde 15 yara var!.

Deldiler göğsümü 15 yerinden,

Sandılar ki vurmaz anık kalbim kederinden!

Kalbim yine çarpıyor,

Kalbim yine çarpacak! !!

Yandı 15 yaradan 15 alev,

Kırıldı göğsümde 15 kara saplı bıçak. .

Kalbim

Kanlı bir bayrak gibi çarpıyor,

ÇAR- PA- CAK!! (Hikmet 1921:180)

\section{Hedef Metin}

ควдо зучмо ${ }^{2}$

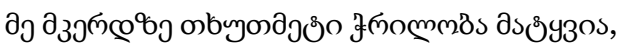

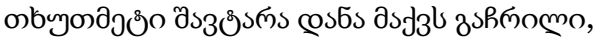

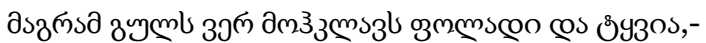

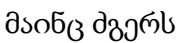

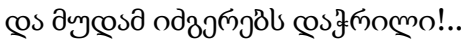

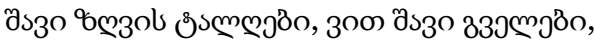

бумлимл $8 \%$ \%

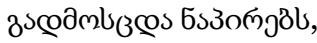

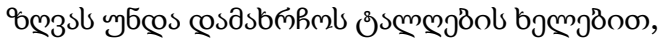

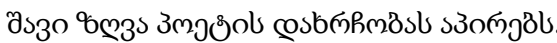

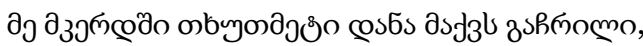

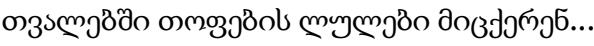

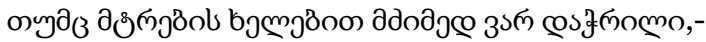

зулмо зо дзоб

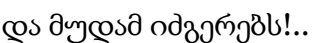

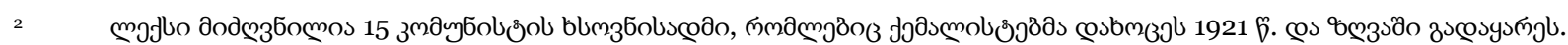

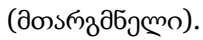

(Şiir, 1921 yılında 15 Kemalist’in öldürülmesi ve denize atılmasına ithafen yazılmıştır. /Çevirmen) 


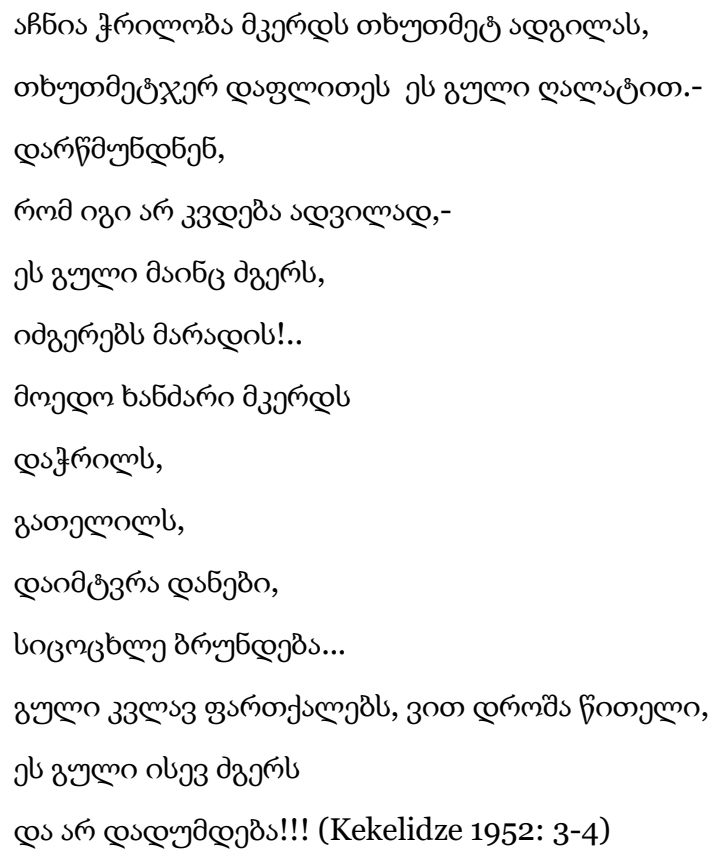

Kaynak şiir 23 satırdan oluşmaktadır. Vakhtang Kekelidze, kaynak şiirin satır sayısına sadık kalamamıştır. Aksine 29 dizeden oluşturarak serbest bir şiir çevirisi izlemiştir. Kaynak şiir ile hedef metin arasındaki satır uyumu şu şekildedir: Birinci-ikinci satırlar arasında kaynak şiirdeki anlam ilişkisi birbirlerine uymaktadır. Hedef metindeki üçüncü satır kaynak şiirde yer almamaktadır. Dördüncü ve beşinci satırlar, kaynak şiirdeki üçüncü ve dördüncü satırları yansıtmaktadır. Kaynak şiirdeki altıncı satır çevrilmemiştir. Altıncı satır kaynak şiirde yedinci satıra denk gelmektedir. Dokuzuncu ve onuncu satırlar kaynak şiirdeki dokuzuncu ve onuncu satırları anlamsal olarak yansıtmaktadır. On ikinci ve on üçüncü satırlar kaynak şiirde yer almamaktadır. On dördüncü ve on beşinci satırlar kaynak şiirde on ikinci ve on üçüncü satırları yansıtmaktadır. Kaynak şiirdeki on beşinci satır çeviride yer almamaktadır. Ancak, on altıncı satırın uzun olabileceği ve şiirin biçimini bozabileceği düşüncesiyle, kaynak şiirde verilen bu bilgi çeviride on sekizinci ve on dokuzuncu satıra taşmıştır. Yirminci ve yirmi birinci satırlar kaynak şiirde on yedinci ve on sekizinci satırları yansıtmaktadır. Yirmi ikinci ve yirmi dokuzuncu arasındaki satılar kaynak metinde yer almamış olup serbest bir çeviri söz konusudur. Ayrıca çeviri metninde şiirin başlığını belirten bir dipnot söz konusudur. Kaynak metinde bu dipnot görülmemektedir. Çevirmenin başlı̆ından yola çıkarak okuyucuya belirtme çabası içerisinde olduğu görülmektedir. Dizeler arası boşluğa dikkat çekildiğinde çeviride bu dikkate alınmamıştır.

\section{Kaynak Metin 2}

\section{KEREM GİBं}

Hava kurşun gibi ağır!!

Bağır

bağır

bağır

bağırıyorum.

Koşun

kurşun 
erit-

-meğe

çağırıyorum...

O diyor ki bana:

- Sen kendi sesinle kül olursun ey!

Kerem

gibi

yana

yana...

«Deeeert

çok,

hemdert

yok»

Yürek-

-lerin

kulak-

-ları

sağır...

Hava kurşun gibi ağır...

Ben diyorum ki ona:

- Kül olayım

Kerem

gibi

yana

yana.

Ben yanmasam

sen yanmasan

biz yanmasak,

nasıl

çıkar

karan-

-liklar

aydın-

-lı̆̆a..

Hava toprak gibi gebe.

Hava kurşun gibi ağır.

Bağır

bağır 
450 / RumeliDE Journal of Language and Literature Studies 2019.S5 (August)

The problem of quality in poetry translations from Turkish to Georgian (poems by Nazim Hikmet) / G. M. Öztürk (p. 441-456)

bağır

bağırıyorum.

Koşun

kurşun

erit-

-meğe

çağırıyorum...(Hikmet 1930:204)

\section{Hedef Metin 2}

Зงวณо วдодgs

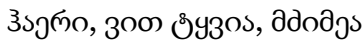

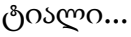

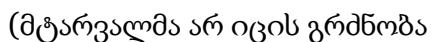

cos costomass).

วง зузоюо...

дว зузопо...

วว зузопо...

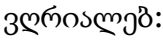

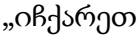

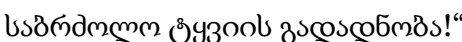

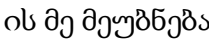

„биу узопо,

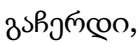

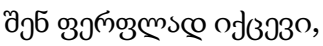

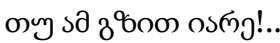

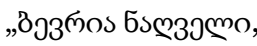

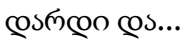

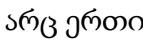

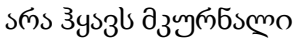

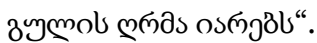

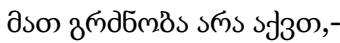

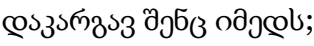

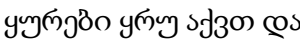

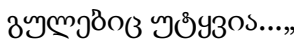

Зงว๓о ддодวร,

зом добь эјьддодј...

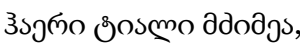

3о0 ภ̊s930s... 


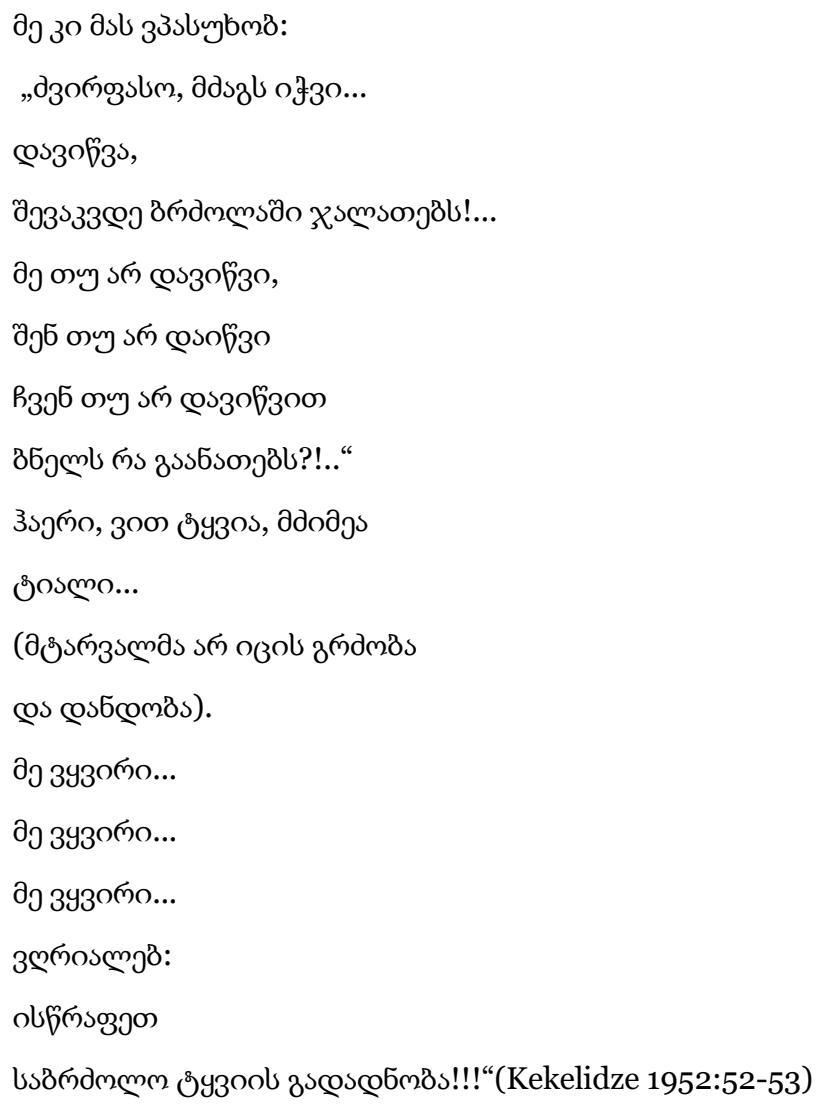

Kekelidze tarafından oluşturulan hedef metin, kaynak metinle aynı dize sayısına sahip değildir. Kaynak metin 51 dizeden oluşurken hedef metin 46 dizeden oluşmaktadır. Nazım Hikmet bu şiiri, kendisiyle aynı yola baş koyan fakat sonrasında o yoldan - kendilerince- çekilmek zorunda kalan ve Nazım'a da bu konuda baskı yapan birkaç arkadaşı için yazmıştır. Böylece "Kerem Gibi" adlı şiirinin başlı̆̆ından yola çıkarsak "Kerem Gibi" anlamı arkadaşlarının onun kavgasının KEREM İLE ASLI'nın aşkına benzetmelerindendir. Kekelidze tarafından hedef metne aktarımı ise tamamen şiirin ilk cümlesinde yer

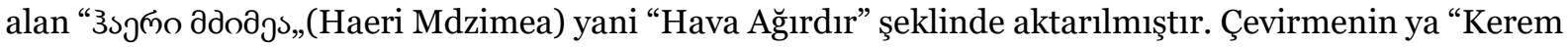
Gibi” anlamının Kerem ile Aslı aşkının ifade edildiğini anlamadığından böyle bir yola çıktığını ya da çeviri metninde "Kerem gibi" ifadesini kullanarak hedef metin okuyucusunun anlamasının güç olacağını düşündüğünden bu tarz çeviriye başvurmuş olabileceğini düşünmemize neden olmaktadır. Dizeler arası boşluğa dikkat çekildiğinde ise hedef metnin yirmi altıncı ve kırkıncı dizelerinden sonra çeviri de buna yer verilmediği göze çapmakta çevirmenin serbest bir biçimsel çeviriye başvurduğunu söylememiz yerinde olacaktır.

\section{Kaynak Metin 3}

SES

Çeneni avuçlarının içine alıp,

duvara dalıp

kalma!.

Çeneni avuçlarının içine alma!.

Kalk!

Pencereye gel! 


\section{Bak!}

Dışarda gece bir cenup denizi gibi güzel, çarpıyor pencerene dalgaları..

Gel!

Dinle havaları:

havalar seslerin yoludur,

havalar seslerle doludur:

toprağın, suyun, yıldızların

ve bizim seslerimizle...

Pencereye gel!

Havaları dinle bir:

Sesimiz yanındadır,

sesimiz seninledir...(Hikmet 1933: 385)

\section{Hedef Metin 3}

bəgß̊o

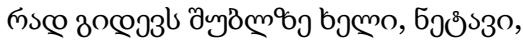

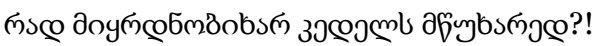

sœjo!

дmœo!

sufor oss 30

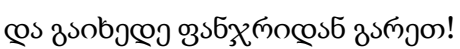

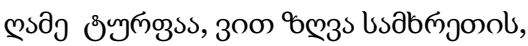

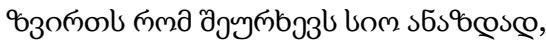

дмсо,

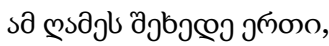

дмщоo,

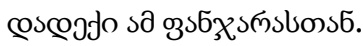

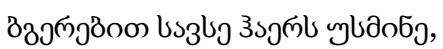

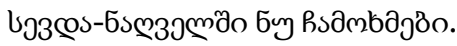

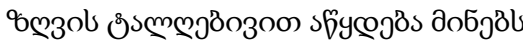

dof̧ol,

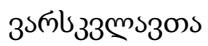

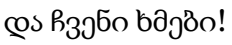

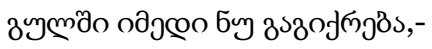

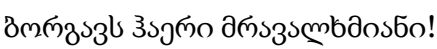

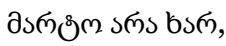

əృбомsб ofб 


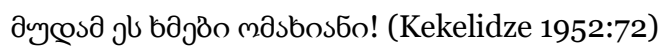

Yukarıda verdiğimiz şiir örneğinde ilk olarak dikkat çekici unsur kaynak metnin başlığıdır. Kaynak

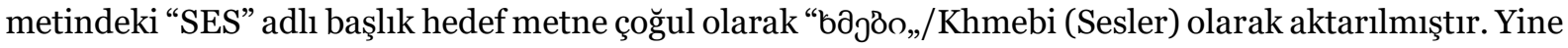
dize sayısına dikkat çekersek kaynak metinde 19 iken, hedef metinde 23 diziden oluştuğunu görmekteyiz. Kaynak metnin ilk dizesinde "Çeneni avuçlarının içine alıp" ifadesini hedef metne "ms@ zо৫ birinci dizesinde çevirmenin yanlış okumasından kaynaklanan sapma söz konusudur. Kaynak metnin birinci dizesindeki "alın" kelimesi hedef metne "çene" olarak çevrilmiştir. Bu durum kaynak şiirin yapısını bozmuştur. Kaynak metnin ikinci dizesi, hedef metinde olmayan "üzüntülü bir şekilde" anlamında kullanılan "af̧øbs rgos" (Mtsukhareba) kelimesi kullanılmıştır. Kaynak metnin üçüncü ve dördüncü dizesi, hedef metinde yer almamaktadır. Hedef metnin üçüncü dizesi kaynak metnin beşinci dizesine denk gelmektedir. Hedef metnin beşinci dizesi kaynak metinde görülmemektir ve Kaynak metinin altıncı ve yedinci dizesi hedef metinde altıncı dizede yer almaktadır. Kaynak metnin sekizinci dizesinde yer alan Arapça “cenup" kelimesi hedef metne çevirmen tarafından doğrudan, anlaşlır şekilde aktarılmıştır. Bu da çevirmenin Arapçaya da hâkim olduğunun bir göstergesidir. Kaynak metnin onuncu dizesi hedef metinin dokuzuncu dizesine denk gelmektedir. Kaynak metindeki on birinci dize hedef metinde yer almaktadır. Ayrıca hedef metinin on birinci ve on ikinci dizeleri kaynak metnin 16 dizesine denk gelmektedir. Kaynak metnin on üçüncü dizesi hedef metnin on üçüncü dizesine denk gelmektedir. Aktarımda bir sorun yoktur. Hedef metnin on dördüncü ve on beşinci dizesi kaynak metinde olmayan tamamen çevirmen tarafından yaratılmış yeni bir söz öbeğidir ve kaynak metnin anlamsal bütünlüğüyle alakası yoktur. Kaynak metnin on dördüncü dizesi hedef metnin on altıncı ve on yedinci dizelerinde görmekteyiz fakat kaynak metindeki "su" ifadesi hedef metne aktarılmamıştır. Kaynak metnin on beşinci dizesi hedef metinde on sekizinci dizede yer almaktadır. Hedef metnin on dokuzuncu, yirminci ve yirmi birinci dizesi kaynak metinde yer almamış ve kaynak metin bütünlüğüyle alakası yoktur. Kaynak metnin on sekizinci ve on dokuzuncu dizelerini hedef metinde yirmi ikinci ve yirmi üçüncü dizelerinde görmekteyiz ama anlamsal açıdan kaynak metne sadık kalınmıştır.

\title{
Kaynak Metin 4
}

\author{
SIRADAKININ ÖLÜMÜ \\ $\mathrm{O}$, ne önde \\ ne arkada \\ sirada \\ siramızdaydl.. \\ Ve yanındakinin kanlı başı onun omuzuna eğilince \\ ona sira gelince \\ sayını saydı... \\ Söz istemez. \\ Yaşlı göz istemez. \\ çelenk melenk lazım değil...
}

SUSUN.

SIRA NEFERİ UYUSUN...(Hikmet 1930: 223) 


\section{Hedef Metin 4}

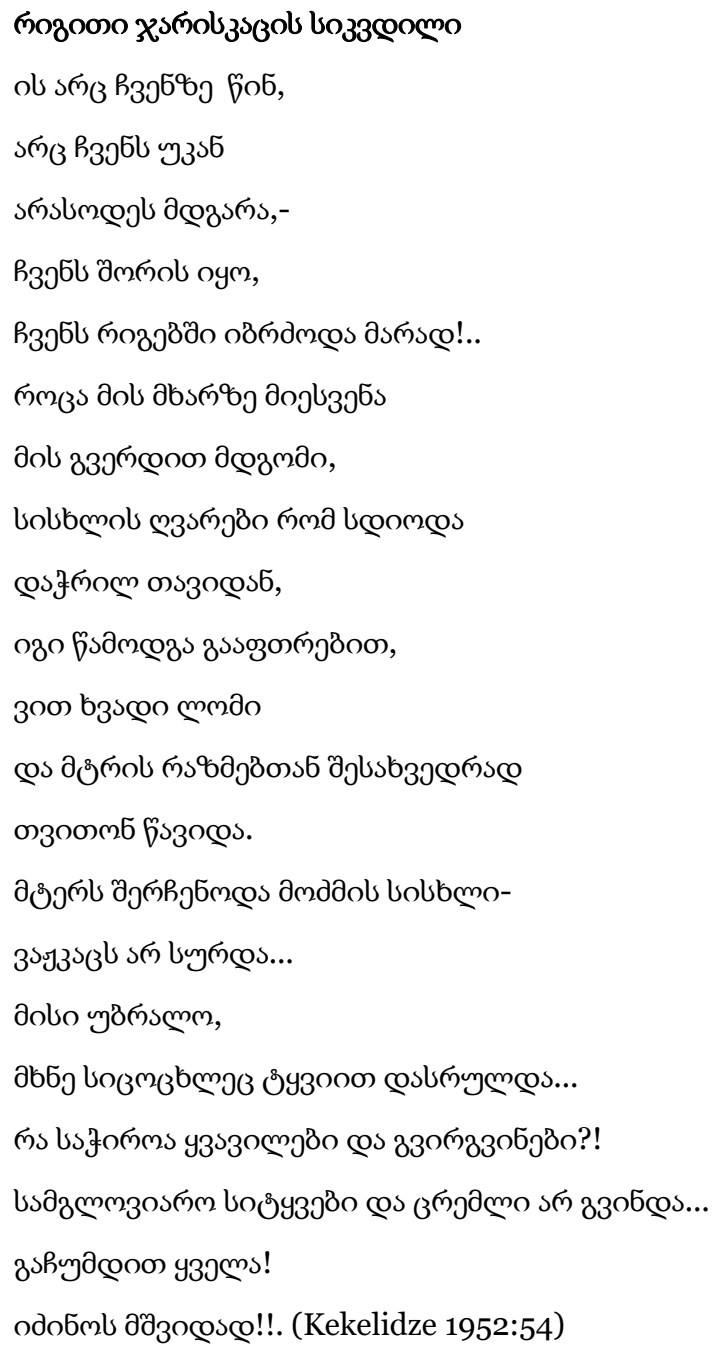

Kekelidze'nin oluşturduğu hedef metinden yola çıkarak birkaç problemle karşılaşmaktayız. Öncelikle hedef metin, kaynak metinle dize sayısı bakımından farklılık söz konusudur. Yukarıdaki örnekte de görüldüğü gibi kaynak metin 12 dizeden oluşurken, hedef metin 21 dizeden oluşmaktadır. Buradan çevirmenin biçimsel yönden serbest bir çeviri izlediği söylenebilir. Bir diğer problem ise hedef metin

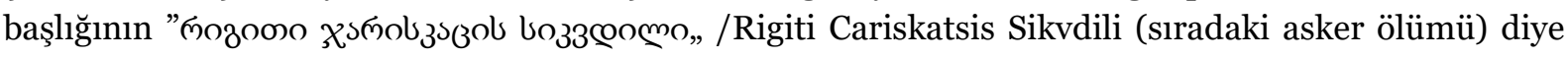
çevrilerek hedef metin başlığını şiirin içeriğine göre başlıkta ekleme yaptığı görülmektedir. Kaynak metnin üçüncü ve dördüncü dizeleri hedef metinde görememekteyiz. Ayrıca hedef metnin beşinci ve altıncı dizeleri kaynak metnin beşinci dizesinde yer almaktadır. Kaynak metnin altıncı dizesinden onuncu dizesine kadarki metni hedef metinde tamamen farklı şekilde çevrildiğini görmekteyiz. tamamen çevirmence yeniden yazılmış, kaynak metinle alakası olmayan dizelerdir. Çevirmen, hedef dilin kültürünü, yazın geleneğini, dilbilgisel yapısını, okuyucu beklentilerini göz önünde bulundurup bir takım ekleme-eksiltmelere başvurabilir ama bütün bunlar kaynak metnin ruhunu zedelemeden olmalıdır. Bahsi geçen dizelerde ise anlamsal bir yıkım vardır. Çevirmen, şairin üslubunu ve kaynak şiirin estetiğini yansıtamamaktadır. Ayrıca kaynak metinle dilbilgisel yönden farklılığı da söz konusudur. Sonuçta şiirlerin belli bir edebi dili vardır. Buradan yola çıkarak şiir çevirisinin zorluğunu da göz önüne alırsak çevirmen yine de hedef metne aktarımında kaynak metindeki anlamsal ve biçimsel 
yönünü bozmadan aktarılmalıdır. Hedef metni oluşturan dizelerin büyük çoğunluğu birbirleriyle alakasızdır; anlamsal örgü bütünlüğü yoktur. Kaynak metindeki işlevsel kelimeler; kişileştirme, benzetme, alışılmamış bağdaştırma gibi söz sanatları hedef metne anlaşılmaz, garip söz öbekleri olarak çevrilmiştir. Sonuçta kaynak metni yansıtmadığı gibi hedef kültüre de bir katkı sağlamayan, anlaşılması zor, uyumsuz dizelerden oluşan yeterlik ve kabul edilebilirlikten uzak bir metin ortaya çıkmıştır. Kaynak metnin on ikinci ve on birinci dizeleri şiirdeki duygusallığı ifade eden cümlelerdir. Hedef metinde yirminci ve yirmi birinci dizelerinde birebir aktararak o duyguyu yaşatabilmiştir.

\section{Sonuç}

Yapılan incelemeler sonucunda Nazım Hikmetin 1952 yllında Tiflis'te yayımlanan ve çevirmen, Türkolog Vakhtang Kekelidze tarafından çevrilen Türkçeye aktarılan 34 şiirinden 4 şiirini biçimsel yönden, dize sayısı bakımından, dizeler arası ilişkilerini incelediğimizde genel olarak bunlara dikkat çekmediğini hedef metin okuyucusuna yönelik bir çeviri yaptığı görülmektedir. Şunu da belirtmek gerekirse, çevirmen karmaşık yapıdaki kaynak metinlere hâkim olduğunda cümle düzeyinde hedef metne doğrudan aktarabilmiştir.

Kaynak metinde yer alan anlamsal, duygusal çağrışımları kuvvetlendiren alışılmamış bağdaştırmalar, yan anlamların ve sıfatların birkaçını hedef metin şiirine yansıtılamadığı saptanmıştır. Bunun temel sebebinin de çevirmenin kaynak metnin dünyasına girememesi, şairin sanat dilini iyi anlayamaması diye düşünebiliriz. Ayrıca kaynak şiirin ritim, tempo, kafiye gibi özelliklerini incelediğimizde 4 şiirde bu uyumu yakalayamamıştır. Çevirmen hedef okuyucusunun anlamasına yönelik çeviri anlayışı benimsediğinden bu uyuma dikkat çekmemiştir. Ama diğer yönden düşünürsek Gürcü dilinin yapısı farklı olduğundan ve bir ifade birkaç kelimeyle ifade edildiğinden bu yola başvurduğunu da söylememiz yerinde olacaktır. Şiir çevirisi bilindiği üzere zor bir iş ve uğraştır. Elbette ki birebir bir çeviri istenemez ama çevirmenin de hem biçimsel hem de anlamsal yönden hedef dil okuyucusuna aktarım yapması gerekir. Aksine anlam karışıklığına ve kaynak metin şiirin biçimsel olarak bozulmasına neden olacaktır.

Sonuç olarak, bütün bunları ele aldığımızda, Kekelidze tarafından Gürcüceye tercüme edilen Nazım Hikmet’in şiirleri, kaynak metinden tamamen uzak olmasa da anlamsal yönden başarılı bir şekilde hedef dil okuyucusuna aktarabilmiştir. Bazen kaynak şiirin üslubu, kişileştirmeleri ve bazı kelime tekrarları birçok eklemelerle dizeler oluşturularak hedef metne aktarılmıştır.

\section{Kaynakça}

Aksan, D. (1995). Şiir Dili ve Türk Şiir Dili. Ankara: Engin Yayınevi.

Aksan, D. (2013). Şiir Dili ve Türk Şiir Dili. Ankara: Bilgi Yayınevi.

Aksoy, N. B. (2002). Geçmişten Günümüze Yazın Çevirisi. Ankara: İmge Yayınevi.

Bengi-Öner, I. (1999). Çeviri Bir Süreçtir...Ya Çeviribilim. İstanbul: Sel Yayıncılık.

Bonnefoy, Y. (1992). Translating Poetry. Theories of Translation (J. Biguenet ve R. Schulte, Ed.) in. Chicago: The University of Chicago Press.

Cary, E. (1960). Şiir Çevirisi. Tercüme Dergisi, ss. 104-110.

Connolly, D. (2005). Poetry Tarnslation. Routhledge Encyclopedia of Translation Studies. London\&Newyork; Routledge. Ed. Mona Baker, ss. 170-176.

Dağbaşı, G. (2017). Arapçadan Türkçeye Yapılan Şiir Çevirilerinde Nitelik Sorunu. 21. Yüzyılda Eğitim ve Toplum Dergisi, ss. 117-195. 
Dahlgren, M. (2000). A Relevance-Based Approach to Poetry Translation. Perspectives, 8(2), 97-108. DOI: 10.1080/0907676X.2000.9961377.

Durusoy, G. (1998). Apollinaire'nin Şiirlerini Çevirirken Ekinsel ve Biçimsel Farklılıklar. Çeviribilim ve Uygulamaları Dergisi, ss.21-33.

Esteban, C. (2001). Poetry and Translation. Sites. The Journal of Twentieth Century/Contemporary French Studies Revue d'études Français, 5(2), 331340. DOI: 10.1080/10260210108456082 adresinden erişildi.

Eyüpoğlu, S. (1983). Sanat Üzerine Denemeler. İstanbul: Cem Yayınları.

Göktürk, A. (2011). Çeviri: Dillerin Dili. İstanbul: Yapı Kredi.

Gürsel, N. (1978). Şiir Çevirisinde Yöntem. Türk Dili Çeviri Sorunları Özel Sayısı ss.155-158.

Haedens, K. (1961). Şiirin Tanımı. Çev: Lütfi Ay, Türk Dili Özel Sayısı, X, ss. 244-245.

Haleva, B. (2006). Şiir Çevirisine Kuramsal Bakış. Dilbilim, XV: 287298.

Hikmet, N. (2008), Nazım Hikmet Bütün Şiirleri. İstanbul: Yapı Kredi Kültür Sanat Yayınevi.

Jones, F. R. (2010). Poetry Translation, Nationalism and the Wars of the Yugoslav Transition. The Translator, 16(2), 223-253. DOI: 10.1080/13556509.2010.10799470.

Lefevere, A. (1975). Translating poetry: seven strategies an blueprint. Amsterdam: Van Gorcum.

Menemencioğlu, N. (1998). Çeviri Sorunları. Metis Çeviri, ss. 22-14.

Okyavuz, A. (2016). Türkçeden İngilizceye Şiir Çevirisi: Orhan Veli Kanık ve Şair- Çevirmenleri, Hacettepe Üniversitesi Türkiyat Araştırmaları Dergisi, Bahar (24), ss. 193-218.

Pancikidze, D. (1993). Çağdaş Gürcü Çevirisi. Literaturuli Sakartvelo, N1, ss. 2-3.

Pancikidze, D. (1995). Biçimin Eşdeğerlik Sorunu. Tiflis.

Pancikidze, D. (1988). Çeviri Teorisi ve Pratikliği. Tiflis.

Pancikidze, D. (2001). Gürcü Çeviri Tarihi Sorunları. Tiflis.

Pancikidze, D. (2002). Dil, Çeviri, Okuyucu. Tiflis.

Shupala, A. (2000). Translating Classical Chinese Poetry Without a Literal Translation. Translation Review, 6o(1), 14-19. DOI: 10.1080/07374836.2000.10523776.

Tanrıkulu, L. (2018). "Rainer Maria Rilke’nin “Duineser Elegien” Şiirinin Türkçe Çevirilerinin Genel Çeviri Stratejileri Açısından İncelenmesi, Atatürk Üniversitesi Sosyal Bilimler Enstitüsü Dergisi, Mart 2018 22(1): 207-222.

Toury, G. (1980). In Search of a Theory of Translation, Tel Aviv: Porter Institute for Poetics and Semitics. 